\title{
THE INTERNATIONALIZATION OF THE BUSINESS \\ ACTIVITIES FROM THE POINT OF VIEW OF THE CORPORATE SOCIAL RESPONSIBILITY
}

\author{
Iveta UBREŽIOVÁ, Mária JANOŠKOVÁ, Anna DIAČIKOVÁ
}

Catholic University, Faculty of Education in Ruzomberok, Slovak Republic

\begin{abstract}
:
Purpose: The main attention of the submitted abstract is pay to the evaluation of the internationalization of the business activities from the point of view of the Corporate Social Responsibility (CSR) in selected company. We have been determinated the partial goals to achieve the main goal as well as the hypothesis.

Design/methodology/approach: The primary and secondary data were used. In the first part of the article, we are focused on the analysis of the term corporate social responsibility and related concepts. We set the objectives and used methodology. Second, practical part is dealing with evaluation established hypothesis and questionnaire survey, which was filled in by the sample of the company's employees. At the end we summarize the obtained data and findings and based on that, we can express our opinion and recommendations for the future development. The questionnaire was anonymous and was performed on a sample of 50 respondents. We used method of analysis, deduction and method of chi-square contingency test. It is a non-parametrical test by which we can verify the representativeness of the selected sample. The main part of this article includes the description of the questionnaire evaluation and statistical evaluation of our three set research hypotheses. In conclusion, we evaluate the overall results of our practical research and propose recommendations for the future.

Findings: The results show that the CSR in relation to the internationalization of the business and assessment has affected the behaviour of company, stakeholders and employees.

Research limitations: There are no limitations in our research.

Practical implications: There are some recommendations for further practical application of results like the teambuilding activities, corporate events, cooperation with environmental organisations, continuous innovation and implementation of new environmentally friendly production methods and cooperation with environmental organisations for the knowledge transfer to the raise of an awareness about the good practises of the company.

Social implications: Based on obtained results, it depends on the perception of the CSR from internal and external sides of company.
\end{abstract}

Keywords: Corporate Social Responsibility (CSR), international management, company, internationalization, stakeholders

https://doi.org/10.11118/978-80-7509-820-7-0210 


\section{Introduction}

The corporate social responsibility of firms, trying to enter new markets and internationalize their production, is a hot topic, nowadays. Decision makers are solving issues connected to the profit maximization, quality improvement, lowering costs, outsourcing, resources recovery, and satisfaction of stakeholders. Companies, operating on more than one markets, have to adapt their production processes and management to the requirements of the several markets. International employees are more than a common thing in multinational corporations and managers have to respond to the constant changes caused by implementation of new technologies and innovations. In the era of a spread of technologies, the term internationalisation is commonly used in all kinds of business and services. Firms can ensure their future development by getting the knowledge about international activities, innovations and strategies of foreign firms. Globalisation is a next stage of internationalisation. An output of the corporate and industrial globalisation is an increase of an amount of multinational companies. More and more companies, dealing with similar production, are appearing on the market. To beat the competition, firms have to build up a competitive advantage. This is the aim of the management. Managers are responsible for activities within the firm such as planning, organising and controlling. Companies are outsourcing their production, hiring foreign specialists, franchising and licensing, entering new markets and so on. They are dealing with different cultures, behaviour, communication, values, languages, processes, strategies and methods of business. The concept of social responsibility is currently becoming more and more an integral part of the activities of many companies. The very name of the concept speaks about its content. Concept of social responsibility had been rising yet in the beginning of $20^{\text {th }}$ Century and it gradually developed and started to be viewed as an effort of influence of the company's activities to the society. Previously corporations followed up and provided exclusively economical goals. The idea of CSR has been established by Bowen, who is considered as the first theoretician of CSR. In his book "Social Responsibilities of the Businessman" from 1953, he wrote: "Social responsibility presents an obligation of the entrepreneurs who strive for the strategies, make the decisions or perform the actions, which are required by the point of view of the goals and values of our society". According to this theory, the goal of a producer was not the best available satisfaction of the customers, but even the whole society (Bowen, 1953). It means, that it is necessary to take into consideration the relations between CSR and internationalization of business activities. From this point of view, the main objectives of submitted paper is to evaluate the corporate social responsibility of company regarding to the globalisation and internationalisation of the business and assess the influence of the corporate social responsibility of the entity on the stakeholders. The publication of this article is supported by the Slovak Agency KEGA - Project KEGA 005SPU-4/2019 "Theory and Practice of the International 
Management and Entrepreneurship in Multicultural Environment", which is solved at the Department of Management in Poprad (co-researcher workplace), Faculty of Education, Catholic University in Ruzomberok.

\section{Literature review}

In the last decades, corporate social responsibility (CSR) issues have received an increasing attention, with academics, media, civil society, and, more recently, even politicians and regulators emphasizing the importance of CSR. Economists and management scholars, as well as business ethicists, have debated the meaning of CSR, its implementations, and its performance measurement (Gatti et al. 2019, p.961). CSR presents conception that moves not only individual organizations and companies to the sustainable development, but also whole country, it connects its economic development with social inclusion, environmental carrying capacity and institutional quality. In last period there is given more attention to creation of conditions for CSR, mainly not only at the level of individual firms, but also at the level of whole countries, and it becomes strategic priority of government in many states (Antošová, Csikósová, 2013), (Madzík, Budaj, Chocholáková, 2018, p.5). Experts offer also today various interpretation of definition of "Corporate Social Responsibility", but all of them are leaning on principle of neutrality, transparency, engaging and active cooperation with interesting subjects. Several published opinions, processed (Bussard et al. 2005) and (Bylok, 2016, p. 19). Its evaluation in developed countries is integral part of evaluation success in social and economic development. Individual aspects of CSR are communicated not only with expert public, but they become subject of interest of whole society. Acquiring of CSR principles by inhabitants is viewed as decisive base that increase quality of life in the country. On the other, the strong relation between CSR within its three pillars and sustainable development from the viewpoint of agricultural enterprises is explained by (Juríčková et al., 2020, p.2020). Idea Corporate Social Responsibility is not very expressly limited, expert literature provides various interpretation of its definition, which base on the objective principle, involvement, active cooperation with interested subjects and transparency. They are marked with common characteristics, for example universality, spontaneity, and they are orientated to the active cooperation of every interested party with aim to express obligation to the development of quality of life. The most significant critic of CSR was Milton Friedman, who emphasized in his article "The Social Responsibility of Business is to Increase its Profits" (1970) that if a profit is the only goal, it is logical that every profit decreases, even though for the purpose of philanthropy, reduces the value itself. Thanks to his opinions, the second half of the 20th century is characteristic by the effort to maximize the profit. The main argument against the Friedman's criticism of responsible entrepreneurship is the theory of stakeholders introduced by Freeman. It is based on the idea that we shouldn't consider just the owners, but even 
other stakeholders, such as employees, customers, suppliers or the society (BoschBadia et al., 2013, p.12).

\section{Methodology}

The aim of this paper is to evaluate a corporate social responsibility of the company regarding to the globalisation and internationalisation of the business and assess the influence of the corporate social responsibility of the entity on the stakeholders. The research was conducted in February, 2021 attended by 50 respondents from the company. While processing the paper the following hypotheses were formulated:

$\mathrm{H}_{1}$ : We assume that the perception of the corporate social responsibility depends on the financial situation of the company.

$\mathrm{H}_{2}$ : We assume that the perception of the ethical principles of the trade is effected by business activities of company.

$\mathrm{H}_{3}$ : We assume that it is demonstrable that the parent company has more developed perception of the corporate social responsibility than the subsidiaries according to the wider range of resources.

For the evaluation of hypothesis we used method of chi-squar contingency test. It is a non-parametrical test by which we can verify the representativeness of the selected sample.

To detect dependencies between the obtained values we used chi-square test of square contingency with a significance level $\alpha=0,05$. (Matejková, Pietriková, Poláková, 2013). The formula for calculation of the tested criterion is:

$$
\chi^{2}=\sum_{i=1}^{m} \sum_{j=1}^{k} \frac{\left(E_{i j}-T_{i j}\right)^{2}}{T_{i j}}=\frac{\left(\left(\mathrm{a}_{i} \mathrm{~b}_{\mathrm{j}}\right)-\left(\mathrm{a}_{\mathrm{i}} \mathrm{b}_{\mathrm{j}}\right)^{2}\right.}{\left(\mathrm{a}_{\mathrm{j}} \mathrm{b}_{\mathrm{j}}\right)_{0}}
$$

Where:

$m$ - the number of categories of the first character

$\mathrm{k}$ - the number of categories of the second character

$E_{\mathrm{ij}}$ - empirical frequency of the $\mathrm{i}$-th row and $\mathrm{j}$-th column

$\mathrm{T}_{\mathrm{ij}}$ - theoretical frequency of the $\mathrm{i}$-th row and $\mathrm{j}$-th column

When the calculated value is lower than the critical value, there is no statistical dependence between the characters. 


\section{Results and Discussion}

The survey of the social responsibility in company was conducted through the questionnaire in the selected branch office of the company, whereby we can get as much information and opinions as possible from employees about the socially responsible conduct of the business. Other authors present a broad approach to Corporate Social Responsibility (CSR), which aggregates a diversity of issues, such as the environment, labor conditions, and human rights. We addressed the impact of increasing CSR demands during the internationalization of emerging market multinationals (Reis, Molento, 2019, p. 351). This survey consists of 11 questions, and it is anonymous. The best possible assessment of the issue in the company required, that the survey involved a large sample of respondents. This survey was conducted on a sample of 50 respondents of different age, gender and qualification structure. From all 50 respondents there were 29 women and $21 \mathrm{men}$. The perception of the corporate social responsibility could be influenced by the number of employees in the operation. The studied entity is taken as a medium enterprise and it has currently 220 employees from which around $65 \%$ are women. The operations have some foreign managers and employees, but mostly the staff is formed by local workers from the region. According to respondents, the enterprise is having very good relations with its shareholders, suppliers, and business partners. Mostly those are loyal, long-lasting partners, that is why the results were so positive. The $46,9 \%$ of respondents think that managers of the company are giving a strong effort to keep the positive relations with their stakeholders. Each company wants to ensure profit and it depends on the turnover. With financial situation in firms, including dairy industry deals Esmerino et al. (2017). That is why the positive relations are so important. Each business activity must be reconciled with the ethical principles of trade. To be a part of the European Union, businesses must respect the rules and principles of fair trade. The following question was determined as a hypothesis. In the terms of the environmental policy, the company is using environmentally friendly work practices according to the EU regulations. In the terms of the environmental policy, the company is using environmentally friendly work practices according to the EU regulations. We can gladly say, that more than $93 \%$ of respondents think that the waste policy of the company is enough. Protecting the environment is beneficial for the nature, humans and the enterprises also. The company is operating almost all around the world. Each country has specific trade conditions, but in the era of globalization, governments are trying to protect more and more the natural environment. According to the $78 \%$ of questionnaire respondents, the company is dealing with this case on the high level, but since the creation of this branch office, the PR management did not have time for organization of special events to support the environmental protection. The company is trying to protect the environment by implementation of environmentally friendly practices and techniques. The headquarters is investing a lot to the research and development. 
One part of this huge investment is a research and development in the field of environmental protection. This also includes recycling processes, transport optimization, and energy and water savings. According to the survey, around $90 \%$ of respondents say that company is purchasing environmentally friendly machinery and equipment. In spite of the fact, that problem of CSR is very worldwide, it gets slowly into awareness in Slovakia. More and more Slovak companies incorporate CSR principles into their practice and learn to profit from its implementation (Ubrežiová, Kozáková, Malejčíková, 2015, p. 542).

\section{Evaluation of hypothesis}

$\mathbf{H}_{1}$ : We assume that the perception of the corporate social responsibility depends on the financial situation of the company. According to our calculation we came to the result that perception of CSR depends on the financial situation of the company because in that case the company has more financial tools to make CSR. Our result is based on the fact that Chi-square test of a square contingence equals to $\chi^{2}=3,824$ and the critical value is 2,159 .

$\mathbf{H}_{2}$ : We assume that the perception of the ethical principles of the trade is effected by business activities of company. Based on the assumption that there is a dependence between the perception of the CSR and the ethical principles of the trade, we prepared the Chi-square test of a square contingence and calculated $\chi^{2}$ and the critical value. Our hypothesis was confirmed and we can say that there is statistical dependence. The results were $\chi^{2}=2,562$ and the critical value equals 2,128 . This may be due to the fact that the company focuses on the CSR, the more it cares about the ethical principles of the trade.

$\mathbf{H}_{3}$ : We assume that it is demonstrable that the parent company has more developed perception of the corporate social responsibility than the subsidiaries according to the wider range of resources. To find out the dependence between parent company and the daughter company and their perception of the corporate social responsibility we used Chi-square test of a square contingence. $\chi^{2}=2,835$ and the critical value is 3,841 . Based on the results of the analysis we can say that between the characters parent-daughter company and their level of the perception of the CSR there is no statistical dependence. But according to the answers in the survey, most of the respondents said that the mother company is more focused on the corporate social responsibility and it does more according to it. 


\section{Conclusion}

Corporate social responsibility is an obligation of each enterprise, which is operating with respect to the environment, society and the economy. Evaluation of the hypotheses showed us, that there were slight deviations between the critical values and calculated values. In our case, we found out that the perception of CSR depends on the financial situation of the company because in that case the company has more financial tools to make CSR, there is a dependence between the perception of the CSR and the ethical principles of the trade, and between the characters parentdaughter company and their level of the perception of the CSR there is no statistical dependence, but according to the answers in the survey, most of the respondents said that the mother company is more focused on the corporate social responsibility and it does more towards it. We can give some recommendations for the future development of the company's perception of the corporate social responsibility and these could be regarding to the business activities that the company could offer some trainings to prepare the employees more on the changes and innovations, to support the community, management of the company can organize some sport events or barbecues to create a relationship with neighbors and potential future employees. Continuous innovation and implementation of new environmentally friendly production methods and cooperation with environmental organizations for the knowledge transfer can contribute to the raise of an awareness about the good practices of the company. Very important is to keep good relationships with regular customers and also attracting the new possible ones by implementation of innovative customer care and production.

\section{References}

1. Antošová, M., \& Csikósová, A. (2013). Corporate Social Responsibility in context of regional development. Saarbrücken: LAP LAMBERT Academic Publishing.

2. Bosch-Badia, M. T., Montlor-Serrats, J., \& Tarrazon, M. A. (2013). Corporate Social Responsibility from Friedman to Porter and Kramer. Theroretical Economics Letters, 3(2013), 11-15. [online] www.file.scirp.org/pdf/ TEL_2013061813184987.pdf (access 305-2021)

3. Bowen, H. R. (1953). Social Responsibilities of the Businessman. New York: Harper \& Brothers.

4. Bylok, F. (2016). The Concept of Corporate Social Reposponsibilty in Strategies of SMEs. Club of Economics in Miskolc' TMP Vol. 12., Nr. 1., pp. 19-26. 2016. http://dx.doi.org/10.18096/TMP.2016.01.03

5. Bussard, A. et al. (2005). Corporate Social Responsibility (in Slovak). Bratislava: Nadacia Integra.

6. Esmerino, E.A., Ferraz, J.E., Tavares Filho, T.F., Pinto, L.P.F., Freitas,M.Q., Cruz,A.G., Bolini, H.M.A. (2017). Consumers'perception toward 3 different fermented dairy products: Insihts from focus groups, word association, and projective mapping. Jounal of Dairy Science, vo. 100, no. 11, p. 8849-8860. https://doi.org./10.3168/jds.2016-12533 
7. Friedman, M. (1970). The social responsibility of business is to increase its profits. coloradu.edu. [online] www.colorado.edu/ studentgroups/libertarians/issues/friedman-soc-resp-business. html

8. Gatti, L., Vishawanath, B., Seele, P., Cottier, B. (2019). Are We Moving Beyond Voluntary CSR? Exploring Theoretical and Managerial Implications of Mandatory CSR Resulting from the New Indian Companies Act? Journal of Business Ethics (2019) 160: 961-972 (access 296-2021 : https://doi.org/10.1007/s10551-018-3783-8

9. Juríčková, Z., Lušnáková, Z., Hallová, M., Horská, E., Hudáková, M. (2020). Environmental Impacts and Attitudes of Agricultural Enterprises for Environmental Protection and Sustainable development. Agriculture 2020, 10, 440. https:// doi.org/ 10.3390/agriculture10100440

10. Madzík, P., Budaj, P., Chocholáková, A. (2018). Practical Experiences with the Application of Corporate Social Responsibility Principles in a Higher Education Environment. Sustainability, 10(6), 1736. https://doi:10.3390/su10061736

11. Matejková, E., Pietriková, M., Poláková, Z. (2013). Praktikum zo Štatistiky. Nitra: SPU

12. Reis, G.G., Molento, C.F.M. (2020). Emerging Market Multinationals and International Corporate Social Responsibility Standards: Bringing Animals to the Fore. Journal of Business Ethics (2020), 166: 351-368. https:// doi.org/10.1007/s10551-019-04144-5

13. Ubrežiová, I., Kozáková, J., Malejčíková, A. (2015). Corporate Social Responsibilty and Perception of Environmental Pillar in the Selected Set of the Slovak Enterprises. Procedia Economics and Finance 34 (2015) 542-549. doi:10.1016/S2212-5671(15)01666-4 